\title{
How (Not) to Run Auctions: the European 3G Telecom Auctions
}

\author{
the latest version of this paper, and related material, will be at \\ http://www.paulklemperer.org \\ Paul Klemperer \\ Nuffield College, Oxford University \\ Oxford OX1 1NF \\ England \\ Int Tel: +441865278588 \\ Int Fax: +44 1865278557 \\ email: paul.klemperer@economics.ox.ac.uk
}

First draft: August 2001

This draft: November 2001

forthcoming European Economic Review, 2002

\begin{abstract}
There were enormous differences in the revenues from the European "third generation" (3G, or "UMTS") mobile-phone license auctions, from 20 Euros per capita in Switzerland to 650 Euros per capita in the U.K., though the values of the licences sold were similar. Poor auction designs in some countries facilitated collusion between firms and failed to attract entrants. The sequencing of the auctions was also crucial. We discuss the auctions in the U.K., Netherlands, Germany, Italy, Austria, Switzerland, Belgium, Greece and Denmark.

JEL Nos: D44 (auctions), L96 (telecommunications).

Keywords: Auctions, Telecommunications, Spectrum Auctions, 3G, UMTS, Bidding.

Acknowledgements: I was the principal auction theorist advising the U.K. government's Radiocommunications Agency, which designed and ran the U.K. mobile-phone license auction described here, but the views expressed in this paper are mine alone. Although some observers thought some of the behaviour described below warranted regulatory investigation, I do not intend to suggest that any of it violates any applicable rules or laws. I am very grateful to the referees and to many colleagues including Bruno Bosco, Jeremy Bulow, Tim Harford, Paul Hofer, Emiel Maasland, Roland Meeks, Margaret Meyer, David Salant, Tommaso Valletti, Mark Williams, and especially Marco Pagnozzi, for helpful advice.
\end{abstract}

(C) Paul Klemperer, 2001 


\section{Introduction}

The 2000-2001 European auctions of "third generation" (3G) mobile telecommunication (or UMTS) licenses were some of the largest in history.

\section{INSERT TABLE 1 HERF}

But Table 1 shows that although the auctions cumulatively raised over $\$ 100$ billion (or over $1 \frac{1}{2} \%$ of GDP) there was enormous variation between countries. ${ }^{1}$ This paper discusses why.

The blocks of spectrum sold were very similar in the different countries, and most analysts assumed a roughly constant per capita value across Western Europe. Smaller countries were said to be worth a little less, centrally located countries were worth a little more (because of the possibilities of expansion to neighbours, and cost savings from sharing fixed costs with them), and richer countries were, of course, worth more. ${ }^{2}$ So the last two effects favour Switzerland, for example, and none of this can explain much of the discrepancies in prices.

The dates of the auctions mattered more, since market sentiment towards $3 \mathrm{G}$ cooled dramatically over the period of the auctions. For example, analysts' estimates of the proceeds from the Swiss auction fell from as high as 1000 Euros per capita after the UK auction was held, to 400-600 Euros per capita in the week before the Swiss auction was due to begin-but this was still a very far cry from the actual outcome of 20 , as was underlined by the enthusiasm with which the lucky winners greeted the Swiss result.

Probably the bidders' valuations of the licenses at the dates of the auctions should have implied proceeds above 300 Euros per capita in all the year-2000 auctions (see Section 5). The lower revenues in the year-2001 auctions can be explained by changed valuations (and Denmark should be counted a success). But much of the variation in the year-2000 outcomes is due to flawed auction designs.

\footnotetext{
${ }^{1}$ Other major European countries used "beauty contest" administrative procedures, with generally dismal results (Klemperer, 2000d; Binmore and Klemperer, 2002).

${ }^{2}$ Other issues affecting license values were population densities, regulatory regimes, and the coverage requirements imposed on the licenses.
} 


\section{What Really Matters in Auction Design?}

Good auction design is really good undergraduate industrial organisation; the two issues that really matter are attracting entry and preventing collusion. ${ }^{3}$

An important consequence is that choosing an ascending auction ${ }^{4}$ is often a mistake for an auctioneer. Ascending auctions allow bidders to use the early rounds to signal to each other how they might "collusively" divide the spoils and, if necessary, use later rounds to punish any rivals who fail to cooperate. Ascending auctions can also deter entry into the bidding since a weaker potential bidder knows that a stronger bidder can always rebid to top any bid he makes.

By contrast, a (first-price) sealed-bid auction ${ }^{5}$ provides no opportunity for either signalling or punishment to support collusion. Furthermore, entry is promoted because a weaker bidder knows he has a better chance of victory. (A stronger bidder doesn't know how much he needs to bid to win, and doesn't want to bid too much because he wants to make a good profit when he does win, so the weaker bidder might win at a price that the stronger bidder would have been willing to bid, but didn’t.)

Of course, sealed-bid auctions are not perfect either. The biggest disadvantage of the sealedbid auction is the flip-side of one of its advantages-because it allows bidders with lower values to sometimes beat opponents with higher values (and so encourages entry) it is more likely to lead to inefficient outcomes than is an ascending auction. ${ }^{6}$ So an auction's design must be tailored both to its environment, and to the designer's objectives. ${ }^{7}$ Auction design is not "one

\footnotetext{
${ }^{3}$ See Klemperer (2000a,c, 2002a). By contrast, a graduate knowledge of modern auction theory is at best of second-order importance and at worst distracting from the main concerns (Klemperer, 2002b).

${ }^{4}$ An ascending auction is the kind of auction typically used to sell an art object or antique. The price starts low and competing bidders raise the price until nobody is prepared to bid any higher, and the final bidder wins the prize at the final price he bid. Mobile-phone licenses are often sold in simultaneous ascending auctions which are much the same except that several licenses are sold at the same time with the price rising on each of them independently, and none of the licenses is finally sold until no-one wishes to bid again on any of them.

${ }^{5}$ In a first-price sealed-bid auction every bidder makes a single "best-and-final" bid, and the winner pays the price he bid.

${ }^{6}$ Of course it is not necessarily socially inefficient to allocate a license to a bidder with a lower value, e.g., if that bidder is a new entrant who will increase competition and hence consumer and social welfare.

Allowing resale is not a perfect substitute for an efficient initial allocation, because resale is itself generally inefficient (Cai, 1997; Myerson and Satterthwaite, 1983; Cramton, Gibbons and Klemperer, 1987).

${ }^{7}$ We assume governments auctioning spectrum licenses care both about efficiency and revenue, because of the substantial deadweight losses of raising government funds by alternative means. (Typical estimates are that deadweight losses are between 17 and 56 cents for every extra $\$ 1$ raised in taxes (Ballard et al., 1985).) The U.K. and Switzerland, at least, were explicit that revenue mattered even though efficiency was the main objective (Binmore and Klemperer, 2002; Wolfstetter, 2001).
} 
size fits all".

Klemperer (2000a) provided a detailed development of these arguments. The European 3G auctions subsequently illustrated their validity. ${ }^{8}$

\section{The Year 2000 Simple Ascending Auctions: the UK, Nether- lands, Italy and Switzerland}

\subsection{The UK Auction (March-April 2000) ${ }^{9}$}

The UK ran the world's first 3G auction. It originally planned to sell just four licenses. The problem we faced was that there were also exactly four incumbent " $2 \mathrm{G}$ " mobile-phone operators who had the advantages over any other bidders of existing $2 \mathrm{G}$ brand-names and customer bases to exploit, and lower costs of building $3 \mathrm{G}$ networks (because of the ability to piggyback on their $2 \mathrm{G}$ infrastructure). We were therefore very concerned that an ascending auction might deter other firms from bidding strongly, or even from entering the auction at all. So the government planned to run a hybrid of the ascending ("English") and sealed-bid ("Dutch") auctions, what we called an "Anglo-Dutch" auction. An ascending auction would have continued until just five bidders remained, after which the five survivors would have made sealed-bids (required to be no lower than the current price level) for the four licenses. ${ }^{10}$ The idea was that the sealed-bid stage would induce some uncertainty about which four of the five "finalists" would win, and entrants would be attracted by the knowledge that they had a chance to make it to the final stage. So the sealed-bid stage would attract entry and so also raise revenue, while the ascending stage would mean less loss of efficiency than might result from a pure sealed-bid auction. The sealedbid stage would also make collusion harder (Klemperer, 2000a, 2002a). The design performed extremely well in laboratory experiments.

However, when it became possible to sell five licenses, a straightforward ascending auction made more sense. Because no bidder was permitted to win more than one license and licenses

\footnotetext{
${ }^{8}$ Klemperer (2000a) was revised as Klemperer (2002a). The papers also give applications to auctions of other commodities than spectrum.

${ }^{9} \mathrm{I}$ was the principal auction theorist advising the Radiocommunications Agency which designed and ran the U.K. auction. Ken Binmore had a leading role and supervised experiments testing the proposed designs. Other academic advisors included Tilman Borgers, Jeremy Bulow, Philippe Jehiel and Joe Swierzbinski.

${ }^{10}$ All four winners would pay the fourth-highest sealed bid and, since the licenses were not quite identical, a final simultaneous ascending stage would follow to allocate the licenses more efficiently among the winners. See Binmore and Klemperer (2002).
} 
could not be divided, there was no simple way to share the spoils, so "tacit" collusion would be hard. Even more important, the fact that at least one license had to go to a new entrant was a sufficient carrot to attract new entrants. In this respect, it was also crucial that the UK was the first in the world to auction the $3 \mathrm{G}$ spectrum so that it was very unclear which new entrant(s) might be successful, and this made it possible to persuade a large number to play the game (see Section 7). Going to market first was a deliberate strategy of the UK auction team, ${ }^{11}$ and the fact that planning had begun in 1997 for a 2000 auction also meant that there was time for a sustained (and very successful) marketing campaign to attract entrants.

So the problems of collusion and entry deterrence that Section 2 emphasized were minimal in the UK context, and efficiency considerations pointed towards an ascending design. ${ }^{12}$

Therefore a version of an ascending auction was actually used, and was widely judged a success; nine new entrants bid strongly against the incumbents, creating intense competition and record-breaking revenues of 39 billion Euros.

For a full account of the auction process, see Binmore and Klemperer (2002).

\subsection{The Netherlands Auction (July 2000)}

The Netherlands' blunder was to follow the actual British design when they had five incumbent operators and five licenses. The equal numbers of incumbents and licenses created exactly the situation in which it could be predicted that very few entrants would bother to show up to an ascending auction. Indeed Klemperer (2000a), quoted in the Dutch press prior to the auction, and Maasland (2000) did predict exactly this.

Recognizing their weak positions, the strongest potential new entrants made deals with incumbents, and Netherlands competition policy was as dysfunctional as its auction design, allowing firms such as Deutsche Telekom, DoCoMo and Hutchison, who were all strong established players in other markets than the Netherlands, to partner with the local incumbents. ${ }^{13}$

\footnotetext{
${ }^{11}$ We deliberately maintained this strategy even when the complications engendered by the VodafoneMannesman takeover battle led many to suggest that the U.K. auction be postponed.

${ }^{12}$ In particular, the five licenses were of very unequal sizes. A sealed-bid component to the design might have resulted in an inefficient allocation of licenses among winners.

${ }^{13}$ A slightly different view is that there may not initially have been a problem because one of the incumbents (Ben) was weak. But after Ben strengthened its hand by joining with Deutsche Telekom there was definitely the same number of strong bidders as licenses, and no hope for entrants in an ascending auction. This view places more of the blame for the auction's failure on weak anti-trust policy, although the ascending design increased the
} 
In the end just one weak entrant (Versatel) competed with the incumbents, and stopped bidding after receiving a letter from an incumbent (Telfort) threatening legal action for damages if Versatel continued to bid. ${ }^{14}$ Although Versatel complained to the government, the government took no action, perhaps because excluding Telfort would have ended the auction immediately, and it might have been hard to impose a meaningful fine. (Hundreds of millions or even billions of Euros would have been required.) The result was that the auction raised less than 3 billion Euros rather than the almost 10 billion Euros the Dutch government had forecast based on the UK experience. ${ }^{15}$

A version of the Anglo-Dutch design would surely have worked better. There are reasons to believe Versatel would have bid higher in the sealed-bid stage than the price at which it quit the ascending auction. And of course the fear of this would have made the incumbents bid higher. Furthermore, the sealed-bid stage would have given weaker bidders a chance (a "hope and dream" in the words of one frustrated potential entrant) which might have attracted more bidders and discouraged the joint-bidding. Most likely the incumbents would still have been the winners, but the revenues would have been much closer to the UK levels that the government had predicted.

Six months later the Dutch parliament began an investigation into the entire auction process.

\subsection{The Italian Auction (October 2000)}

The Italian government thought it had learned from the Netherlands fiasco. It also chose roughly the UK design, with the additional rule that if there were not more "serious" bidders (as tested by various prequalification conditions) than licenses, then the number of licenses could (and probably would) be reduced. At first glance this seemed a clever way to avoid an incentive to joint-venture (see Section 3.4).

${ }^{14}$ Telfort claimed Versatel "believes that its bids will always be surpassed by bids of the other participants in the auction" so it "must be that Versatel is attempting to either raise its competitors' costs or to get access to their $2 \mathrm{G}$ or future $3 \mathrm{G}$ networks", and said it "will hold Versatel liable for all damages as a result of this" (see van Damme, 2002).

${ }^{15}$ The auction's problems were aggravated by the government's belief that it could not legally set binding minimum prices. The rules therefore specified that lots that received no bids at the beginning of the auction would have their minimum prices reduced. Since bidders were permitted to sit out some rounds of bidding, all but one did this at the start of the auction driving the minimum prices down towards zero and making the government look ridiculous. (Starting the prices at zero would have been functionally equivalent and reduced political embarrassment.) Setting a binding reserve price based on the information revealed by the UK auction would clearly have improved the outcome. 
embarrassingly uncompetitive auction à la Netherlands, but (as I and others argued) the plan was badly flawed. It would be "putting the cart before the horse" to withdraw a license and so create an unnecessarily concentrated mobile-phone market just in order to make an auction look good. And the Netherlands auction had anyway made it clear that guaranteeing just one more bidder than license does not guarantee that an ascending auction will be competitive!

By the time of the Italian sale the situation was dramatically different from the one the UK had faced. Most importantly, firms had learned from the earlier auctions who were the strongest bidders, and hence the likely winners, at least in an ascending auction. So weak bidders would not show up or would bid jointly in such an auction (see Section 7), and the number of entrants would be much lower than the 13 who had entered the UK auction. ${ }^{16}$ Furthermore, an ascending auction makes collusive or predatory behaviour much easier if the number of contestants is low (Klemperer 2000a, 2002b). An ascending auction was therefore a much riskier proposition than for the UK.

In the event only six bidders entered the auction to compete for five licenses and one (Blu) then quit after less than two days of bidding and only just above the reserve price. ${ }^{17}$ Although this price was not as absurdly low as in some other countries, it still did not seem to have been set using the information from the UK and German auctions. So the result was per capita revenues below $40 \%$ of the UK level, or less than 14 billion Euros instead of the more than 25 billion Euros that the government had estimated.

While the precise nature of the Italian disaster could not have been predicted, it was clear in advance that the design was not robust. Although the reasons why attracting entry was hard were a little different from the Netherlands, the implication was the same-a sealed-bid or Anglo-Dutch design would have performed better. ${ }^{18}$

\footnotetext{
${ }^{16}$ Two losers in the U.K. auction (Sonera and Telefonica) formed a joint-venture and several weak bidders quit the auction process altogether. Curiously, the Italian government also eliminated two weak bidders prior to the main auction in a "beauty contest" phase.

${ }^{17}$ Government officials claimed there had been "collusion" by which Blu entered simply to avoid invoking the rule reducing the number of licenses, thus allowing every other bidder to win a cheap license. But an investigation found no evidence. Blu was a joint venture between British Telecom and Italian-based firms whose main business was not in telecoms, and perhaps they were unable to agree terms for competing seriously.

${ }^{18}$ Note that firms in a sealed-bid auction want their rivals to think them weak, so other bidders would probably not have gambled on Blu being genuinely weak. Even in the ascending auction they seemed surprised when Blu quit at such a low price. And, of course, in a sealed-bid contest Blu might have bid more, or other firms might have entered. The two weak bidders that the Italian government eliminated prior to the auction (note 16) might
} 


\subsection{The Swiss Auction (November/December 2000)}

Switzerland again copied the UK design and achieved the most embarrassing result of all. The Swiss ran an ascending auction for four licenses, and attracted considerable initial interest from potential bidders. But just as in Italy weaker bidders were put off by the auction form - at least one company hired bidding consultants and then gave up after learning that the ascending-bidding rules would give the company very little chance against stronger rivals. And the government permitted last-minute joint-bidding agreements - essentially officially-sanctioned collusion - so the field shrank from nine bidders to just four (!) in the week before the auction was due to begin. Unfortunately the reserve price had been set ludicrously low given the information available from the preceding European 3G auctions. The government postponed the auction for a month while it tried to change the rules, but this was furiously opposed by the remaining bidders who successfully argued that it was legally obliged to stick to the original rules. ${ }^{19}$ So the bidders had just to pay the reserve price- one-thirtieth per capita of the UK and German prices, and one-fiftieth of what the government had once hoped for. ${ }^{20}$

By contrast, in a sealed-bid (or Anglo-Dutch) design joint-bidding is less attractive because if strong firms bid jointly they increase the opportunity for weaker competitors, so may simply attract other firms into the bidding. For example, Deutsche Telekom or Hutchison who had both won licenses in Germany, Austria, Netherlands, UK, and elsewhere, and who had quit the Swiss auction just one week earlier, might perhaps have re-entered a sealed-bid contest. ${ }^{21}$ So strong firms would have been more likely to bid independently in a sealed-bid auction, and Switzerland might have had a much more competitive auction.

also have scared the stronger bidders into more aggressive bidding if they had been permitted to compete in a "sealed-bid" contest.

${ }^{19}$ By contrast, the U.K. retained the right to cancel its auction in circumstances like these. This also reduced the incentive to joint-venture in the UK.

${ }^{20}$ Actually the auction yielded $2 \frac{1}{2} \%$ more than the reserve price because slight differences between the licenses led to a little competition for the best license.

${ }^{21}$ Although there were also rumors (investigated by the regulator) that Deutsche Telekom "collusively" agreed not to participate in the auction in return for subsequently being able to buy in to one of the winners. 


\section{The Year 2000 "Variable-Prize" Ascending Auctions: Ger- many and Austria}

\subsection{The German Auction (July-August 2000)}

The Germans conformed to national habits (or at least to British stereotypes of them) by choosing a more complex design: Germany auctioned twelve blocks of spectrum from which bidders could create licenses of either two or three blocks, e.g., four firms could win large 3-block licenses or six firms could win smaller 2-block licenses. This contrasted with the previouslydiscussed auctions in which all the licenses were of pre-determined (though not always identical) sizes. As always, firms could win at most one license each. The twelve blocks were sold by a simultaneous ascending auction, much like the previously-discussed auctions.

The point of the design was to let the number of winners be determined by the bidders who might have information unavailable to the government about, e.g., the engineering advantages of large vs. small licenses. But such an auction's outcome is driven by bidders' profits, not by consumers' or social welfare. Klemperer (2000a, 2002a) and Jehiel and Moldovanu (2001) discuss the different distortions that can result. Since the bidding in the British auction had already revealed a lot about bidders' relative valuations of different licenses, ${ }^{22}$ it would have been wiser to fix the number of licenses in advance. ${ }^{23}$

The auction also proved vulnerable to collusion and entry problems: only seven bidders participated. (The entry of weaker bidders was perhaps discouraged by the ascending design, as in other auctions after the UK's, see Section 7.) And one bidder (MobilCom) early on made what looked like a collusive offer to another (Debitel), telling a newspaper that "should [Debitel] fail to secure a license [it could] become a 'virtual network operator' using MobilCom's network

\footnotetext{
${ }^{22}$ The UK auctioned two large (roughly, 3-block) and three small (roughly, 2-block) licenses, and the bidding showed that the strongest new entrants, and probably also the two smaller incumbents, valued small licenses almost as much as large ones, but the two larger incumbents valued large licenses considerably more than small ones, so five or six winners was probably socially correct in the UK. The correct number also depends on the likely competitiveness of the market, which the German regulator is best qualified to judge for Germany.

${ }^{23}$ Not only were consumers' interests unrepresented in the choice of the number of winners, but the auction's complexity generated other potential problems. A bidder might have stayed in the auction in the hope of being one of five winners, but suddenly found itself one of six winners, and been quite unhappy and even tried to default. Also, the possibility that the auction would end with a bidder being the high bidder on just one block, in which case the block would be re-auctioned, created both considerable uncertainty for bidders and the possibility of an inefficient allocation, since the price in the re-auction could be very different from that in the original auction. The government was lucky that these problems did not arise.
} 
while saving on the cost of the license" (Financial Times, 2/8/2000 p.28). Shares in Debitel rose 12 per cent in response to the remarks which, if taken literally, would be similar to the offer of a side-payment for quitting the auction. But, as in the Netherlands case, and probably for similar reasons, the government did not punish MobilCom; in particular, excluding MobilCom would have risked ending the auction almost immediately when the price level was about $3 \%$ of what the auction finally achieved. ${ }^{24}$

Although Debitel did not quit immediately, MobilCom's suggestion might have made dropping out of the auction seem less unattractive, and Debitel did stop bidding at a relatively low level-just $55 \%$ of the per-capita revenue achieved by the UK auction. There were then two natural outcomes, depending on the strategies followed by the two dominant incumbents, Deutsche Telekom and Vodafone-Mannesman, each of whom had about $40 \%$ of the existing German mobile market. Either these dominant firms could raise the price to force the weaker firms among the remaining six to quit, which would yield high revenue for the government but a concentrated industry. Or they could lead all six remaining firms to tacitly "collude" to reduce their demands to two blocks each, thus ending the auction quickly and giving the government a lowish revenue but a more competitive industry. (A problem with the German approach of auctioning many small blocks is that it is often easy for firms to see how to collusively divide them.)

Vodafone-Mannesman ended a number of its bids with the digit "6" which, it was thought, was a signal that its preference was to end the auction quickly with six remaining bidders. ${ }^{25}$

Surprisingly, however, Deutsche Telekom first continued to push up the price while it was well below the levels that the weaker firms had shown themselves willing to pay in the UK auction, but then ended the auction before pushing any of the weaker firms out, giving up just when the price approached the level at which the weaker players had quit the U.K. auction. ${ }^{26}$ Some observers wondered whether Deutsche Telekom's objectives were affected by the fact that it was

\footnotetext{
${ }^{24}$ The government had failed to set a meaningful reserve price.

${ }^{25}$ According to the Financial Times $3 / 11 / 2000$ p.21 "One operator has privately admitted" to this kind of behaviour. A weaker player behaved similarly. It is also understood that Mannesman (successfully) signalled a desire to cooperate with DT in the 1999 2G auction (Klemperer 2002a), and Mannesman may have seen the earlier auction as setting a precedent for behaviour in the $3 \mathrm{G}$ auction.

${ }^{26}$ The two weakest bidders in Germany both quit the U.K. auction very close to its end. One announced in advance of the German auction that it was willing to pay the U.K. price.
} 
majority owned by the German government. ${ }^{27}$ In any case, the government ended up with both high revenues (94\% of the UK revenues per capita) and an unconcentrated mobile-phones market!

But the fragility of the design was emphasized by the Austrian sequel.

\subsection{The Austrian Auction (November 2000)}

Austria mimicked the German design (again conforming to national habits?). Again interest in entering an ascending auction was limited, and just six firms competed for the twelve blocks available. Because the government had set a very low reserve price- just one-eighth of the per capita price that the identical German 3G auction had achieved three months earlier-there was an obvious incentive for the six firms to tacitly agree to divide up the market to obtain two lots each. ${ }^{28}$ Any bidder who might have been inclined to compete for a third unit knew he would have to push the price up a very long way to drive out another bidder (and he would then have to pay this high price on all three units). So the bidding stopped very soon after starting at the reserve price. It is rumoured that the bidding only lasted the few rounds it did in order to create some public perception of genuine competition and reduce the risk of the government changing the rules. The final price was less than one-sixth of the per capita revenue raised in the UK and Germany, and the only reason that Austria did any better than Switzerland was

\footnotetext{
${ }^{27}$ DT's behavior reminds me of my father-in-law whom I often see join a queue but quit in frustration before the front of the line. Rational behavior generally involves sizing up the queue first, and then either quitting quickly (c.f. ending the auction quickly) or gritting one's teeth and waiting to the end (c.f. waiting for another firm to quit the auction.) In fact my father-in-law's behavior might be more rational than DT's, since he might learn about the queue's behavior. DT learnt nothing new after Debitel quit (except that no-one else was quitting), although it might have felt pressured by the stock market response to the climbing auction prices.

(Put more technically, the cost to DT of allowing the price to rise a small bid increment, $\Delta$, before ending the auction approximated $2 \Delta$, while the benefit was the probability of a weaker bidder quitting in the interval $\Delta$ times the value of that outcome. So it cannot have maximised DT's expected profits for DT to end the auction when the probability of a weaker bidder quitting in the next increment was increasing - as it surely was. Grimm et al (2001) argue the behaviour may have been rational, but they use a model that abstracts from this issue.)

Given that DT had pushed up the price so far, should V-M now have changed its strategy and continued pushing the price up further? Not if it retained pessimistic views about the cost of driving out a weaker firm. Furthermore, if V-M, only, had successfully continued to demand three blocks and driven a weaker bidder out, the rules would then have required the re-auction of a block (see note 23) with unpredictable results, and DT might have ended up with three blocks at a much lower price than V-M, an outcome which V-M's management probably wished to avoid. (Grimm et al also abstract from this concern.) In any case, V-M co-operated with DT in ending the auction.

${ }^{28}$ The agreement may not have been completely tacit. The largest incumbent, Telekom Austria was reported the week before the auction as saying it "would be satisfied with just two of the 12 blocks of frequency on offer and if the [ 5 other bidders] behaved similarly, 'it should be possible to get the frequencies on sensible terms'...but that it would bid for a third block if one of its rivals did" (Reuters 31/10/00 Austrian UMTS Auction Unlikely to Scale Peaks). If taken literally, this could be interpreted as both offering a "collusive" deal, and threatening "punishment" if its rivals failed to accept the offer.
} 
that its reserve price was not quite so ridiculously low.

\section{Bidders' Valuations of Licenses}

The available evidence about firms' and the wider market's valuations of the licenses sold in the year 2000 auctions suggests revenues could probably have been in the range 400-650 Euros per capita, and certainly above 300 Euros per capita, in all these countries.

The Netherlands government cancelled its July bond issue in anticipation of receiving over 600 Euros per capita, while the Italian government expected around 450, and the Swiss telecom regulator predicted revenues of around 400 Euros per capita just five days before the auction. Analysts' estimates were consistent with these numbers, or higher, right up to the auction in Italy and Switzerland, and until a month before the Netherlands and Austrian auctions. ${ }^{29}$

It is also clear that the winners of all these four "failed" auctions were delighted-some reports said "euphoric" - about the outcomes. Some non-winners also valued the licenses at higher prices than the winners paid, but were deterred by the auction designs. And when the denouement of the Swiss auction became clear and the government tried to revise the rules, a winner (Swisscom) threatened legal action to preserve the status quo. ${ }^{30}$

Meeks (2001) studies the jumps in Swisscom's share price when the number of bidders in the Swiss auction fell from five to four (for four licenses, thus crippling the auction), and again when the Swiss government dropped its attempt to rewrite the rules. The share-price changes are highly statistically-significant and, controlling for general market movements, correspond to the market expecting that bidders would pay several hundred Euros per capita less in the auction than was earlier anticipated. ${ }^{31}$

\footnotetext{
${ }^{29}$ Later estimates for Austria and the Netherlands reflected these auctions' obvious design-flaws.

${ }^{30}$ Even in the UK where the high revenues took commentators by surprise, several losing bidders seem to have secured funding in advance of the auction to levels that implied revenues of 300 Euros per capita (and all the losers bid at least that far), one winner claimed to have predicted the final price to within $10 \%$, a second winner was said to have guessed the final price to within $20 \%$, and another winner resold a fraction of its license at a profit shortly after the auction. And before the U.K. bidding had gone very high, a new entrant in Germany announced a willingness to pay up to a price that would imply proceeds of around 660 Euros per head from the German auction.

Furthermore Cable et al (2001) analyse share price movements around the UK auction and argue that the market was neither surprised by the prices paid in the UK (the evidence is from movements of the share prices of the incumbents, whose winning was not news, but whose payments were news) nor felt that the winners overpaid (the evidence comes from the share prices of entrants whose winning or losing was news).

${ }^{31}$ The excess returns beyond general European telecom and Swiss market movements correspond to 570 Euros per head at the first event and (after intermediate ups and downs) 190 Euros per head at the second event. A
} 
However, perceptions of the values of $3 \mathrm{G}$ licenses did fall dramatically over the course of the auctions. For example, some analysts marked down expectations of the Swiss proceeds from 1000 Euros per capita to 400-600 Euros per capita between the end of the UK auction and the planned beginning of the Swiss auction (the last of the year-2000 auctions). License values fell even further after the Swiss auction.

In part valuations were caught up in what now seems to have been a dotcom and technology bubble. The Dow Jones European telecom stock price index fell by over one-third between the UK and Swiss auctions, and then fell even more precipitously by almost another $50 \%$ - to less than one-third its level during the UK auction-by the time of the Danish auction. In part there were a number of negative "shocks" about both the development of the $3 \mathrm{G}$ technology itself, and likely consumer interest in it. And the values are highly leveraged since they reflect the difference between the (large) expected revenues and the (also large) expected costs of developing the required network infrastructures. ${ }^{32}$ So a small reduction in expected revenues has a proportionally much larger effect on license values. Furthermore the option values of licenses are not necessarily high since the licenses come with "roll-out" investment requirements attached to them.

In 2001, valuations collapsed. ${ }^{33}$ Typical analysts' estimates prior to all the year-2001 auctions were around one-tenth of the levels predicted the year before, or about 50 Euros per capita.

\section{The Year 2001 Auctions}

\subsection{The Belgian and Greek Auctions (March and July 2001)}

Not only were valuations low by Spring 2001, but Belgium and Greece seemed particularly unattractive to new entrants. In Belgium a very dominant incumbent (Belgacom's Proximus)

95\% confidence interval is +/- 320 Euros per head so the first event, at least, suggests a change of at least 250 Euros per head in the expected revenues from the auction hence that expected revenues from the auction had been (well) over 250 Euros per head.

${ }^{32}$ The costs of building infrastructure were estimated to be far more than was paid for licenses.

${ }^{33}$ The collapse seems to have been gradual. The French beauty contest in late January 2001 suggested valuations were still one-third to one-half the previous summer's levels. (Two firms agreed to pay the French government a price corresponding to total proceeds of 330 Euros per capita, while others probably valued licenses this highly but refused to pay so much in the hope of negotiating a lower price.) 
had two-thirds of the existing mobile market and was substantially owned, and many people thought favoured, by the state. Greece is not a rich country. So probably little more could be done in these countries than set an appropriate reserve price to the incumbent operators who had established second-generation customer bases and therefore still valued $3 \mathrm{G}$.

Both countries held auctions for 4 licenses - and in each case attracted only the 3 incumbents, who therefore obtained licenses at the reserve prices which yielded about 45 Euros per capita in each case.

It is very hard to argue plausibly that an auction design deterred much entry when a license goes unsold, ${ }^{34}$ and there is also no obvious reason to criticise the reserve prices that these governments chose. Indeed their auctions yielded more than twice the per capita revenue of the Swiss farce, even though, as discussed, their timing was much less propitious and their markets are much less profitable. ${ }^{35}$

\subsection{The Danish Auction (September 2001)}

The Danes, who ran the last of the western European auctions, were in a particularly tricky position. Not only were valuations still very low, ${ }^{36}$ but Denmark planned to sell the same number of licenses (four) as it had incumbent operators - exactly the situation that the Netherlands had so spectacularly fumbled. But the Danish designers had in fact read Klemperer (2000a), and they took its arguments seriously. Denmark chose a sealed-bid auction to give weaker bidders a chance of winning, in the hope both of attracting new entrants and of scaring the incumbent operators into making higher bids. ${ }^{37}$

\footnotetext{
${ }^{34}$ Furthermore, although the Belgians just copied the UK design, the Greek rules made the payment terms much easier (effectively lowering the reserve price) if a fourth bidder appeared - so the government was willing to sacrifice revenue to attract an additional entrant and create a more competitive market for $3 \mathrm{G}$ services. And if five or more bidders had appeared, the Greek auction would have used sealed bids-making entry yet more attractive.

${ }^{35}$ In particular, Greece's GDP per head is less than one-third of Switzerland's, and its neighbours-Albania, Macedonia, Bulgaria, Turkey - do not quite stack up against Switzerland's - Germany, France, Austria, Italy (and of course Liechtenstein) - or make it a key piece of the European puzzle.

${ }^{36}$ In a defining moment in the $3 \mathrm{G}$ process, shortly before the Danish auction, a new entrant in Norway (Sonera) handed the license it had won in the previous year's beauty contest back to the government for free, completely writing off its investment. Admittedly Norway is an unattractive market and the licensees must pay annual fees but "In spite of Sonera splashing out 4 billion Euros on licenses, most analysts now value them at zero" (Financial Times August 11/12, 2001, p.1).

${ }^{37}$ The designers saw little point in running an Anglo-Dutch auction, since the chance of attracting many new entrants was very tiny in the Danish context, and with just one new entrant (the actual outcome) a sealed-bid auction is equivalent. The auction was a sealed-bid auction in which all bidders paid the fourth-highest bid (and only this bid was revealed), and the government pre-committed to keeping the number of bidders secret in the
} 
It was a resounding success, attracting a serious bid from a new entrant and shocking analysts with revenues of 95 Euros per capita, or almost double most expectations. ${ }^{38}, 39,40$

\section{How did the Sequencing Matter?}

The entry and collusion problems of the later auctions were exacerbated by the very fact that they were later.

\subsection{Learning to Play the Game}

It is notable that the only successful auctions (from the seller's viewpoint) were the first of their type; there was enough time between plays of the European game for bidders to learn from the early auctions and adjust their strategies for the later ones.

The UK's successful simple ascending auction design was closely copied by the Netherlands, Italy and Switzerland, with results that, we have seen, went from bad (Netherlands and Italy), to worse (Switzerland). The UK sale taught firms the costs of participating in a competitive auction, and they became increasingly successful at forming joint-ventures that ensured the subsequent auctions were less competitive. ${ }^{41}$

We also saw that the German auction followed the UK and Netherlands auctions, but was a more complex ("variable-prize") ascending design. The dominant firms clearly misplayed their hands, with excellent results from the government's viewpoint. But when the Austrians copied the German design three months later, the firms had learnt to coordinate their behavior during hope of scaring better bids from the incumbents even if no new entrant actually bid.

${ }^{38}$ Some semi-formal support for our views about the relative successes of different auctions is provided by a simple OLS regression of price per capita on the Dow Jones European telecom stock price index (a measure of market sentiment). The UK, Denmark and Germany performed much better than the model predicted, while Austria, Switzerland, and the Netherlands were the worst performers. Italy also appears among the worst performers if population is also included in the regression (small countries are said to be worth less per capita). Otherwise including population, GDP per head, mobile usage, or internet usage makes little difference, as do several other natural specifications.

${ }^{39}$ In fact the entrant was one of the winners, squeezing out an incumbent. The losing incumbent will presumably pursue $3 \mathrm{G}$ as a virtual network operator (the Danish government mandates licensees to rent spectrum to VNO's). So the new entrant has probably increased the competitiveness of the ultimate $3 \mathrm{G}$ market.

${ }^{40}$ At almost the same time as the Danish auction, Hong Kong also planned to sell four licences. Hong Kong originally planned a design similar to Denmark's but the strong incumbents successfully lobbied to change to a simple ascending auction - and there were just four entrants for the four licenses, even though Hong Kong was thought an attractive market.

${ }^{41}$ And while the firms became more sophisticated, the governments became less sophisticated, leaving out safeguards that were in the UK auction (see, e.g., note 19) and using the UK's design in inappropriate contexts; unlike the UK's auction which spent three years in planning and development, some subsequent auctions were rushed, last-minute affairs. 
the auction, and it was the firms that won the Austrian round.

Finally the Danes pulled off a success with a sealed-bid design. We have argued that this kind of design may prove more robust to future gaming by firms but that, of course, remains to be seen.

\subsection{Learning Opponents' Valuations}

The previous sub-section assumes firms need to learn because they are boundedly rational, rather than because they lack information. But firms also learn about their rivals, and this was critical to why the first auction, the UK's, had 13 bidders while no subsequent auction had more than seven.

Firms learnt from the UK auction whether they had any realistic chance of victory, and companies that recognised they were clearly outgunned did not want to invest their time and effort in bidding in later auctions. ${ }^{42}$ Certainly they did not want to bid in ascending auctions which pretty much guarantee the strongest bidders will win.

Furthermore, a bidder who learnt that others' valuations were somewhat higher than its might have figured that its best hope was to buy or lease part of a license after the auctions. In this case the bidder might have stayed out of the later auctions to keep its valuation private and so strengthen its bargaining position in the aftermarket. Again, this may be a particular problem in ascending auctions since they make losers' valuations more transparent. ${ }^{43}$

The elimination of some firms, and the fact that the remainder had learnt something about each other's valuations for the licenses, may both have been important factors in making bargaining between the bidders easier, facilitating the joint ventures and "collusion" that emerged in the later auctions. ${ }^{44}$

\footnotetext{
${ }^{42}$ The effects in this sub-section might be mitigated if firms recognised that their opponents might bid aggressively in order to persuade them not to enter subsequent auctions, although this would be a further reason for higher prices in early auctions. Pagnozzi (in progress) is exploring the issues in this section.

${ }^{43}$ With private values and straightforward bidding up to one's value, the losers' values are perfectly revealed. (Bidders who foresee this will not bid so straightforwardly - this is just another version of our point - but entering the auction may still reveal information that could be damaging later.) Managerial incentives and compensation mechanisms may also mean that resale could not easily be at a lower price than in the original auction. And tacit collusion that rewards a non-bidder with a lower resale price would also encourage non-participation (see note 21). Of course these issues are only significant when sharing a license is (privately) efficient and renting or partial resale is easy.

${ }^{44}$ To illustrate why a tighter distribution of beliefs about opponents' valuations facilitates bargaining, imagine two firms with privately-known values for a single license, independently drawn from a distribution with lowerbound zero, and decreasing hazard rate. Then bargaining is "very hard" in the sense that the expected ex-ante
} 


\subsection{Complementarities}

Markets that were auctioned later were more valuable to those who had won earlier ones that fitted well with them in a network, and an early win also allowed a firm to influence suppliers about the development of the technology in ways that would help the firm in later markets. These "real" complementarities reinforced the learning effects discussed in the previous subsection, and further discouraged losers of early auctions from entering later auctions, especially ascending ones. $.^{45}, 46$

\subsection{Budget Constraints}

It is hard to believe that capital-market constraints mean many very profitable investments are foregone. However, if some bidders faced higher financing costs than others then, as above, even a slight relative weakness could have encouraged them to quit the auction process, at least as long as ascending auctions were being used. It is certainly clear that many firms were caught by surprise by the change in market sentiment towards telecoms, and some firms faced difficulties in borrowing.

The issues in this section clearly need more careful analysis; the area seems ripe for research. ${ }^{47}$

joint surplus (before knowing either firm's value) from competing in an ascending auction exceeds the joint surplus from colluding to divide the prize equally at price zero. (If bidders' values, $v$, are independently drawn from distribution $F(v)=1-e^{-\lambda v}$-i.e., constant hazard rate $\lambda$-the winner's profits from an auction equals the expected distance between the values, $\frac{1}{\lambda}$, which equals the expected average value.)

With increasing hazard rates, bargaining is not "very hard" in this sense. For example, with values uniformly distributed on $[0,1]$, bidders' expected joint surplus from the auction is $\frac{1}{3}$, but is $\frac{1}{2}$ from agreeing to divide the pie at a price of zero. So successful bargaining seems more likely, at least before bidders have invested to determine their own values.

But even in the latter case, bargaining is still "hard" in the sense that a bidder who knows he has the highestpossible value expects the same private surplus $\left(\frac{1}{2}\right)$ from the auction as from collusion at a price of zero. So, with even a tiny cost of negotiating, opening negotiations might be taken to be the bad signal that one's value is not very high, and-depending on the model-neither player may be willing to make the first offer. "Easy" bargaining, in this sense, requires a still tighter distribution of valuations.

${ }^{45}$ Bikhchandani (1988), Bulow and Klemperer (2002), Bulow, Huang and Klemperer (1999), Klemperer (1998) and Klemperer and Pagnozzi (2002) emphasise how small differences in bidders' valuations can have dramatic effects on prices achieved by ascending auctions.

${ }^{46}$ Awareness of these effects probably encouraged more aggressive bidding in the earlier auctions, further accentuating the downward trend in prices. The effects were mitigated by budget constraints.

${ }^{47}$ A "declining price anomaly" is often observed in the sequential auction of identical objects such as art, wine, real-estate, radio-transponders (Ashenfelter, 1989, Beggs and Graddy, 1997, Harford, 1998, Klemperer, 1999, $2000 \mathrm{~b}$, Milgrom and Weber, 2000). But the issues in Sections 7.1 and 7.2 are probably more important than the explanations usually given for this. I also know no evidence of bidders colluding by taking turns to win the auctions; most likely there were too many players with different strengths and interests. And the auction in any given country was probably too large a one-off event to be treated as a single play in a repeated game of some kind in that country. 


\section{Conclusion}

A key determinant of success of the European telecom auctions was how well their designs attracted entry and discouraged collusion (as is true for most auctions, see Klemperer, 2002a). The sequencing of the auctions exacerbated the entry and collusion problems.

The organisers of most of the auctions after the UK's, and of the Netherlands and Swiss auctions in particular, failed to give enough attention to attracting entry, and magnified their problems by permitting joint-bidding agreements prior to the auctions. The German and Austrian auctions demonstrated the vulnerability of ascending auctions to "collusive" behaviour during the auctions, and there were also rumors of collusion in the ascending auctions in Italy, the Netherlands, and Switzerland. All these problems were aggravated by most later auctioneers' failure to use the information from the UK auction to set sensible reserve prices.

The auctions also showed that auction design is not "one size fits all". The ascending design that worked very well for the UK worked very badly in the Netherlands, Italy, and Switzerland because of entry problems, and this was predictable (and predicted) in advance. These other countries would clearly have done better if they had included a sealed-bid component in their auctions, as Denmark did, and as the UK would have done if entry had been a concern there.

We have emphasised the revenues generated by the different auctions because they differed so greatly. "Assigning the spectrum efficiently", interpreted roughly to mean maximising the sum of the valuations of those awarded licenses, was most governments' main objective, but we cannot assess whether the auctions achieved this. ${ }^{48}$ There was no obvious inefficiency, but there also seems no reason to believe that alternative designs (such as the Anglo-Dutch) would have been much less efficient, and they would have yielded higher revenues from some of the sales. Whether it would have been better to run a single grand European auction is beyond our scope. ${ }^{49}$ But there was no appetite for a coordinated process at the time and, as we saw, the UK did well to steal a march on its rivals by going it alone and auctioning first.

\footnotetext{
${ }^{48}$ See Börgers and Dustmann (2001) and Plott and Salmon (2001).

${ }^{49} \mathrm{~A}$ simultaneous auction of all the continent's spectrum might have alleviated the entry problems that some countries faced, and helped companies build the particular networks of licenses that most interested them (in the actual process companies had to bid in early auctions without knowing what they would win later on). On the other hand, it would have been harder to prevent collusion. An auction for all radiospectrum including TV and radio, etc., might also allocate the spectrum more efficiently between different uses.
} 


\section{References}

Ashenfelter, O., 1989. How Auctions Work for Wine and Art. Journal of Economic Perspectives $3,23-36$.

Ballard, C., Shoven, J., Whalley, J., 1985. General Equilibrium Computations of the Marginal Welfare Costs of Taxes in the United States. American Economic Review $75,128-138$.

Beggs, A., Graddy, K., 1997. Declining Values and the Afternoon Effect: Evidence from Art Auctions. Rand Journal of Economics 28, 544-65.

Bikhchandani, S., 1988. Reputation in Repeated Second-price Auctions. Journal of Economic Theory 46, 97-119.

Binmore, K., Klemperer, P., 2002. The Biggest Auction Ever: the Sale of the British 3G Telecom Licences. The Economic Journal, forthcoming.

Börgers, T., Dustmann, C., 2001. Strange Bids: Bidding Behaviour in the United Kingdom's Third Generation Spectrum Auction. Working Paper, University College, London.

Bulow, J., Klemperer, P., 2002. Prices and The Winner's Curse. Rand Journal of Economics, forthcoming.

Bulow, J., Huang, M., Klemperer, P., 1999. Toeholds and Takeovers. Journal of Political Economy 107, 427-454.

Cable, J., Henley, A., Holland, K. (2001). Pot of Gold or Winner's Curse?

An event study of the auctions of 3G mobile telephone licences in the UK", Working Paper, School of Management and Business, University of Wales, Aberystwyth.

Cai, H-B, 1997. Delay in Multilateral Bargaining under Complete Information. Working Paper, Los Angeles, University of California.

Cramton, P., Gibbons, R., Klemperer, P., 1987. Dissolving a Partnership Efficiently. Econometrica, 55, 615-32.

Grimm, V., Riedel, F., Wolfstetter, E., 2001. The Third Generation (UMTS) Spectrum Auction in Germany. Working Paper, Humboldt Universitat zu Berlin.

Harford, T., 1998. Sequential auctions with financially constrained bidders. M. Phil thesis, 
Oxford University, available at www.timharford.com.

Jehiel, P., Moldovanu, B., 2001. The European UMTS/IMT-2000 License Auctions. Working Paper, University College London and University of Mannheim.

Klemperer, P., 1998. Auctions with Almost Common Values. European Economic Review 42, $757-69$.

Klemperer, P., 1999. Auction Theory: A Guide to the Literature. Journal of Economic Surveys 13(3), 227-286. (Also reprinted in The Current State of Economic Science. (1999).

S. Dahiya, ed. 2, pp. 711-766.)

Klemperer, P., 2000a. What Really Matters in Auction Design. May 2000 version, available at www.paulklemperer.org.

Klemperer, P., 2000b. The Economic Theory of Auctions (ed.). Cheltenham, U.K.: Edward Elgar.

Klemperer, P., 2000c. Why Every Economist Should Learn Some Auction Theory. Forthcoming In: Dewatripont, M., Hansen, L., Turnovsky, S. (Eds.), Advances in Economics and Econometrics: Invited Lectures to Eighth World Congress of the Econometric Society, Cambridge, U.K.: Cambridge University Press, and available at www.paulklemperer.org. Klemperer, P., 2000d. Spectrum on the Block. Wall Street Journal, Oct 5. p.8 and available at www.paulklemperer.org.

Klemperer, P., 2002a. What Really Matters In Auction Design. Journal of Economic Perspectives, forthcoming.

Klemperer, P., 2002b. Using and Abusing Economic Theory. Forthcoming at www.paulklemperer.org.

Klemperer, P., Pagnozzi, M., 2002. Advantaged Bidders and Spectrum Prices: An Empirical Analysis. In press at www.paulklemperer.org.

Maasland, E., 2000. Veilingmiljarden Zijn een Fictie (Billions from Auctions: Wishful Thinking). ESB June 9: p. 479 and translation available at www.paulklemperer.org. Meeks, R., 2001. An Event Study of the Swiss UMTS Auction. Research Note, Nuffield College, Oxford University. 
Milgrom, P., Weber, R., 2000. A Theory of Auctions and Competitive Bidding: II.

In: Klemperer, P. (Ed.), The Economic Theory of Auctions. Edward Elgar, Cheltenham, U.K.: .

Myerson, R., Satterthwaite, M., 1983. Efficient Mechanisms for Bilateral Trade.

Journal of Economic Theory, 29, 265-81.

Pagnozzi, M. (2002). Post-auction Takeovers. Working paper in press, Oxford University.

Plott, C., Salmon, T., 2001. The Simultaneous, Ascending Auction: Dynamics of Price Adjustment in Experiments and in the Field. Mimeo, California Institute of Technology and Florida State University.

van Damme, E., 2002. UMTS-Auctions in Europe. Working Paper. Tilburg University, Netherlands.

Wolfstetter, E., 2001. The Swiss UMTS spectrum auction flop: Bad luck or bad design? Working paper, Humboldt Universitat zu Berlin 
Revenues from European 3G Mobile Spectrum Auctions

Euros per capita

Year 2000

Austria

Germany

Italy

Netherlands

Switzerland

UK

Belgium

615

240

Denmark

95

Greece

45

[TABLE 1]

20

650 